Journal of Food Sciences; Suez Canal University, 2018

\title{
Quality Characteristics of Compound Chocolate Enriched with Dried Indian Cherry Fruit Pulp
}

\author{
Abbas O. Toliba \\ Food Science Department, Faculty of Agriculture, Zagazig University, Egypt
}

Received: $3 / 12 / 2018$

\begin{abstract}
The effect of the addition of dried Indian cherry (Cordia dichotoma) fruit pulp on the colour, texture and sensory attributes of compound chocolate was evaluated. The obtained results revealed that the dried Indian cherry fruit pulps contained $12.60 \%$ moisture, $68.28 \%$ carbohydrate, $4.07 \%$ crude protein, $6.19 \%$ crude fiber, $4.27 \%$ fat and $2.32 \%$ ash. The addition of dried Indian cherry fruit pulp increased the firmness of the resultant products. On the other hand, the three CIE values $L^{*}, a^{*}$ and $b^{*}$ reflected a good colour for the resultant chocolate. Moreover, There were no significant differences $(\mathrm{p}<0.05)$ for colour, odour, flavour, sweetness, texture, melting quality and global quality for all studied chocolate samples, only astringency had a significant differences $(\mathrm{p}<0.05)$. It could be concluded that the addition of dried Indian cherry fruit pulp (up to 40\%) to compound chocolate manufacturing produced a new flavored chocolate with a good sensory attributes.
\end{abstract}

Keywords: Cordia dichotoma, compound chocolate, firmness, colour, sensory properties

\section{INTRODUCTION}

Indian cherry (Cordia dichotoma Forst, Synonym: Lisura or Lasora) is a small to moderate size plant of family Boraginaceae. Fruits are $1.3-2.5 \mathrm{~cm}$ long globose or ovoid glossy, yellowish brown, pinkish or nearly black when ripe, usually single seed surrounded by a transparent, sticky, sweet edible pulp (Vidyasagar et al., 2010). Cordia dichotoma is one of the traditional medicinally important deciduous plants available all over India and other wormer regions (Pawar et al., 2018). The fruits turn dark on ripening and the pulp gets viscid and produces a sticky, jelly-like mass called Cordia dichotoma gum (Pawar and Jadhav, 2015).

The whole plant of Cordia dichotoma is edible and is used as food. Immature fruits are pickled and are also used as vegetable (Jamkhande et al., 2013). Also, it was found that the using of Cordia myxa fruit extract or its powder as stabilizer for ice cream production produced a better quality with low cost product (AlHamdani, 2017). The flowers of Cordia dichotoma and curd milk mixture used to protect human body against the negative effects of sun waves (Pawar et al., 2018). The full ripe fruits were used for preparing a Cordia dichotoma juice with high acceptability (Toliba, 2012). Also the fruits of Indian cherry (Cordia dichotoma) were dried for nutrition and food purposes after processing with different pretreatments (Toliba, 2018).

The plant parts of Cordia dichotoma such as leaves, fruit, bark and seed have many health benefits and it have been recorded for keeping anti-diabetic, antiulcer, anti-inflammatory, immune modulator, general hypolipidemic effect and analgesic activity. (Jamkhande et al., 2013; El-Newary et al., 2016; Pawar et al., 2018). Cordia dichotoma fruit is a delicious fruit particularly admired by children. The fruit is slimy, juicy and helps in the curing of mouth ulcers, strengthening of teeth and gums. It is also used as an ingredient in preparations to relieve urinary tract infection (Patil et al., 2010).

*Corresponding author e-mail: beso14omar@yahoo.com
Cordia dichotoma fruits contained $74.87-82.46 \%$ moisture, $1.98-2.8 \%$ protein, $1.6-2.0 \%$ fat, $13.0-17.0 \%$ carbohydrate and $2.0-2.91 \%$ ash. Cordia dichotoma fruits is a rich source of vitamin $C$, calcium, phosphorus, potassium, magnesium and iron (Valvi and Rathod, 2011; Toliba, 2012). The extracts of Cordia dichotoma possessed antibacterial and antioxidant activities (Rajashekar et al., 2014).

Chocolate is one of the most famous craved foods in the world markets. It has a particular attractive taste and might be useful for human health. The demand of this food appears to be mainly due to its potential to arouse sensory pleasure and positive emotions. Chocolate is perceived as a comfort food and has been reported to be craved and consumed during depressive moods. (Serafini et al., 2003; Macht and Dettmer, 2006; El-kalyoubi et al., 2011). The product may have many forms and consistency and may be stuffed or covered (Leite et al., 2013). Differences in the sensory characters of chocolate can be attributed to the use of different cocoa types, variations in ingredient proportions, use of milk crumb instead of milk powder, blending techniques and processing methods (Elkalyoubi et al., 2011). Researchers are still investigating the best formulation, a method of extraction, physical properties, rheological behavior and sensory perception of the compound chocolate (Hussain et al., 2018).

Compound chocolates provide confectioners with an alternative to chocolate that is both economical and convenient. Compound chocolates can be used either to enrobe centers (biscuits, fruits, nuts, ice cream, etc.) or be formed into shells for subsequent filling (Talbot, 2009). They have a good product structure as the vegetable fats used are solid at ambient temperatures and above, but still melt at mouth temperature which usually around $37^{\circ} \mathrm{C}$ (Rosales et al., 2017).

No information is available on the use of Indian cherry fruits in the compound chocolate enrichment. Hence, this study was to evaluate the influence of dried Indian cherry fruit pulp enrichment on the quality 
characteristics (colour, texture and sensory properties) of compound chocolate.

\section{MATERIALS AND METHODS}

\section{Materials}

Ripe Indian cherry (Cordia dichotoma Forst) fruits were collected from a private Farm in Kafr-Sakre, Sharkia Governorate, Egypt during summer 2017. The fruits were carefully washed using tap water at airconditioned room temperature $22 \pm 2{ }^{\circ} \mathrm{C}$. Ready to use compound cooking chocolate was purchased from a local supermarket in Zagazig city, Egypt. As described on the compound chocolate package it consists of sugar, cocoa butter substitute, cocoa powder, soya lecithin (E322), salt and vanillin. All chemicals were purchased from El-Gomhorya Company Branch, Zagazig City, Egypt.

\section{Methods}

\section{Dehydration of Indian cherry fruit pulp:}

The edible pulp of Indian cherry fruits was manually separated by removing the non-edible parts (stone and sticky pulp) and carefully washed to remove the traces of the sticky pulp. The fruit pulp was soaked in $2 \%$ citric $+2 \%$ ascorbic acid solution (to prevent the browning colours) for $5 \mathrm{~min}$ at room temperature $\left(22 \pm 2^{\circ} \mathrm{C}\right)$. The fruit pulp was directly dried as described by Toliba (2018) using a hot-air oven at $65^{\circ} \mathrm{C}$ for 7.5 hrs. The dried product was packaged in a polyethylene packages till used

\section{Chocolate manufacturing:}

Kitchen compound chocolate produced from a famous company was melted in a water-bath at $50^{\circ} \mathrm{C}$ for $30 \mathrm{~min}$ and then mixed with dried Indian cherry fruit powder (the grinding of dried fruit pulp was performed using a grinder, Moulinex, France) with the ratios 20, 30 and $40 \%$. The liquid mixture was molded by poured to solidify in a silicon chocolate former star shape. Separately whole halves of dried Indian cherry fruit pulps were directly dipped as it is, in the melted chocolate. All chocolate treatments were placed in the refrigerator at $4 \pm 2^{\circ} \mathrm{C}$ for $15 \mathrm{~min}$ for hardening. The formed compound chocolate samples were removed from the former and all chocolate samples were packed in a polyethylene packages and restored at the refrigerator till used. The control of compound chocolate was free from Indian cherry fruits and produced by the same technique. Figure (1) showed the photo of prepared chocolates.
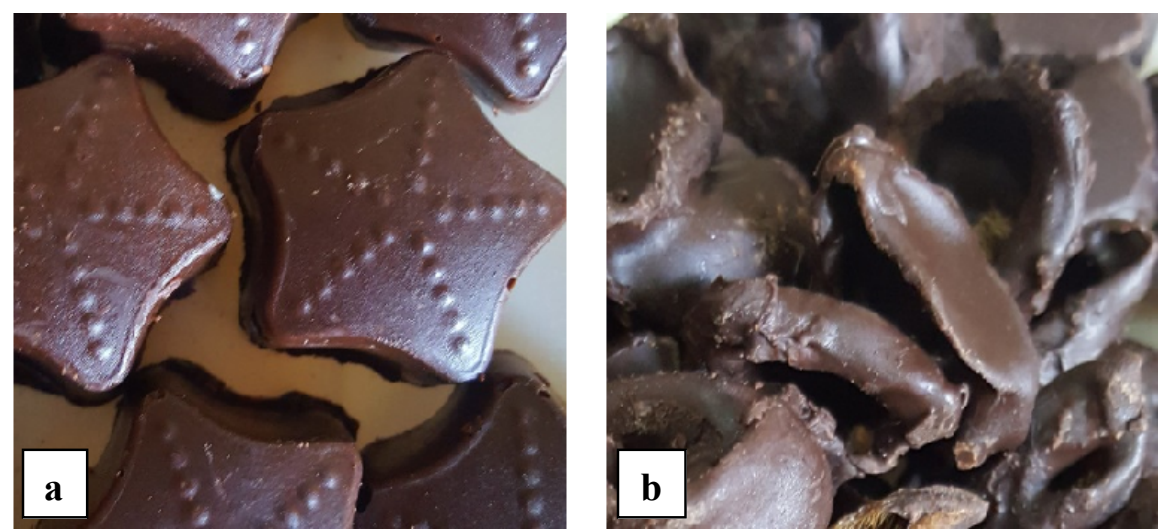

Figure (1): Photos of compound chocolate containing dried Indian cherry fruit pulps: (a) grounded fruits and (b) whole fruit pieces dipped in chocolate

\section{Proximate composition determination:}

The dried Indian cherry fruit pulp were analyzed for moisture, carbohydrate, protein, crude fibers, fat, ash contents as described by Ranganna (2003).

\section{Colour analysis determination:}

Hunter Lab colour analyzer (Hunter Lab Color Flex EZ, USA) calibrated with white and black ceramic reference standard was used to determine the color attributes (lightness $L^{*}$, redness $a^{*}$ and yellowness $b^{*}$ ) of compound chocolate samples as summarized by Hussain et al. (2018).

\section{Texture analysis determination:}

Texture analysis of compound chocolate samples was measured using a texture analyzer (TA-XT plus, stable micro systems, UK), connected to a computer with the software as described by Ashkezary et al. (2018). Test settings were as follows: test mode: compression, pre-test speed: $1 \mathrm{~mm} / \mathrm{sec}$, test-speed: 3 $\mathrm{mm} / \mathrm{s}$, post-test speed: $10 \mathrm{~mm} / \mathrm{s}$, distance $23.0 \mathrm{~mm}$, strain $10.0 \%$, trigger type: button, trigger force: $5.0 \mathrm{~g}$, probe: HDP/SR. Firmness was taken as the maximum peak force in Newton. Results for hardness are expressed as the mean value of three replicates conducted on each sample.

\section{Sensory evaluation:}

The sensory evaluation of the five chocolate samples were conducted with ten consumers of varied ages and gender, who were students, professors and employees of Food Science Department, Faculty of Agriculture, Zagazig University as described by Leite $e t$ al. (2013). A nine-point structured hedonic scale $(1=$ disliked extremely and $9=$ liked extremely) was used in 
the acceptance test to evaluate the colour, odour, flavour, sweetness, texture, melting quality, astringency and global quality of the samples and the means were taken. The chocolate samples served at room temperature $\left(22 \pm 2^{\circ} \mathrm{C}\right)$.

\section{Statistical analysis:}

Data collected on different parameters were analyzed statistically by using MSTAT-C programme (Anonymous, 1986) for analysis of variance and means were compared using Fisher's protected least significant differences (LSD) test at 5\% probability level (Steel et al., 1997). Standard division (SD) was calculated. Means having the same letters are not significantly different.

\section{RESULTS AND DISCUSSION}

Proximate composition of dried Indian cherry fruit pulp:

Table (1) presented the results of proximate composition of dried Indian cherry fruit pulp. Moisture content was $78.97 \pm 2.04$ for fresh Indian cherry fruit pulp. The dried fruit pulp contained 12.60 \pm 1.02 Moisture, $68.28 \pm 1.25$ carbohydrate, $4.07 \pm 0.47$ crude protein, $6.19 \pm 1.64$ crude fiber, $4.27 \pm 0.72$ fat and $2.32 \pm 0.83$ ash. These results are in agreement with those reported by Valvi and Rathod (2011) and Toliba (2012). Figure (2) showed the photos of fresh and dried Indian cherry fruit pulps.

Table (1): Proximate composition (\%) of dried Indian cherry fruit pulp (Mean \pm SD)

\begin{tabular}{lccccccc}
\hline Component (\%) & Moisture & Carbohydrate & $\begin{array}{c}\text { Crude } \\
\text { protein }\end{array}$ & $\begin{array}{c}\text { Crude } \\
\text { fiber }\end{array}$ & Fat & Ash \\
\hline $\begin{array}{l}\text { Dried Indian cherry } \\
\text { fruit pulp }\end{array}$ & 12.60 & 68.28 & 4.07 & 6.19 & 4.27 & 2.32 \\
& \pm 1.02 & \pm 1.25 & \pm 0.47 & \pm 1.64 & \pm 0.72 & \pm 0.83 \\
\hline
\end{tabular}
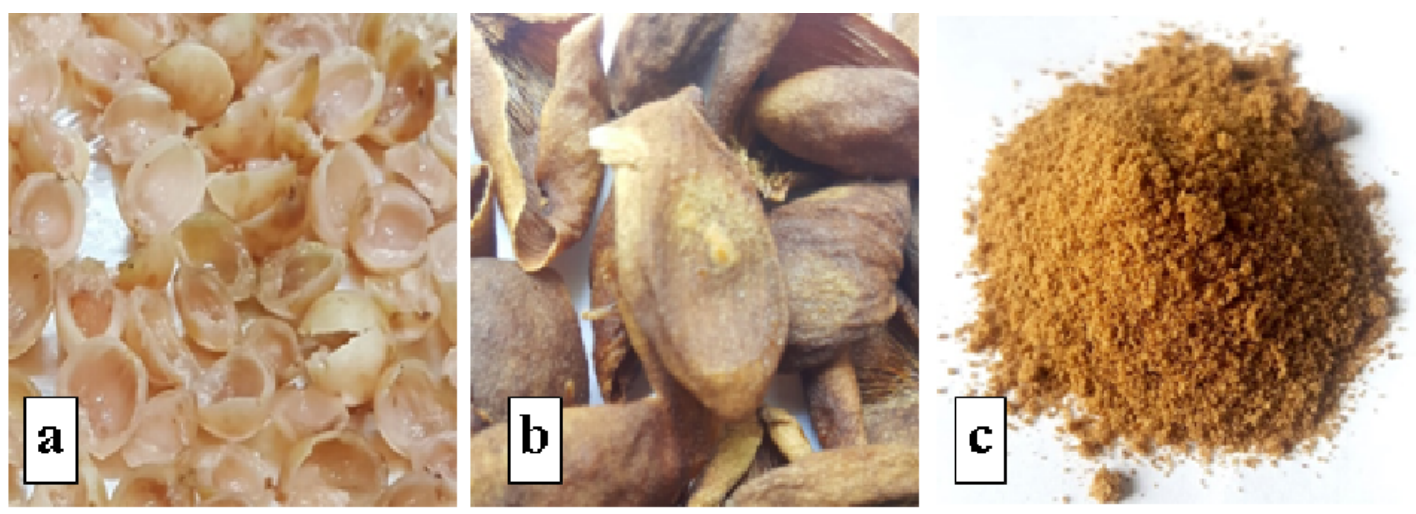

Figure (2): Photos of fresh (a), dried whole pieces (b) and dried powder (c) of Indian Cherry (Cordia dichotoma) fruit pulps

\section{Compound chocolate manufacturing:}

\section{Colour attributes:}

The foods colour may be affected by different optical phenomena like scattering and the morphology of food surface. Therefore, a full understanding of the influence of surface topography on measured color is important (Hussain et al., 2018). CIE $L^{*} a * b *$ system was used for colour measurements of compound chocolate samples and the results are presented in Table (2). Generally, the three CIE values reflected a good chocolate colour for resultant chocolate as compared with earlier studies such as those reported by Popov-Raljic and Lalicic-Petronijevic (2009) and Hussain et al. (2018). However, $L^{*}$ value ranged between $23.62 \pm 1.54$ to $26.78 \pm 1.03, a^{*}$ value $5.50 \pm 0.69$ to $6.96 \pm 1.06$ and $b^{*}$ value $4.37 \pm 0.45$ to $4.94 \pm 1.37$.

\section{Texture:}

Texture of food is a combination of the physical structure of the material and its mechanical and surface properties (Andrae-Nightingale et al., 2009). Generally, the result of the stable micro systems test is an average of the forces required to compress, shear, puncture or extrude the sample of variable geometry. The maximum force and area under the curve are usually recorded for all of these types of test and taken as an indication of bulk firmness. The area under the curve is usually termed the 'work of shear, compression or penetration' a larger value indicating a firmer sample (Novaković and Tomašević, 2017).

Texture results of compound chocolate containing dried Indian cherry fruit pulp was presented in Table (3) and Figure (3). As expected, firmness increased by increasing the levels of Indian cherry fruit pulp in the compound chocolate samples. The compound chocolate free from Indian cherry fruit pulp was the softest and the dried Indian cherry fruit pulp coated with compound chocolate was the hardest (Table 3 ). Generally, firmness of all compound chocolate samples ranged from 2.46 to $63.47 \mathrm{~N}$ while, the work of shear ranged from 598.63 to $20781.88 \mathrm{~g}$. sec. 
Table (2): Colour attributes (Mean \pm SD) of compound chocolate containing different levels of dried Indian cherry fruit pulp (whole pieces or grounded fruit)

\begin{tabular}{|c|c|c|c|c|}
\hline \multirow[b]{2}{*}{ Sample } & & \multicolumn{3}{|c|}{ Colour value } \\
\hline & & $\begin{array}{c}L^{*} \\
\text { Lightness }\end{array}$ & $\begin{array}{c}a^{*} \\
\text { Redness }\end{array}$ & $\begin{array}{c}b^{*} \\
\text { Yellowness }\end{array}$ \\
\hline \multicolumn{2}{|l|}{ Compound chocolate (control) } & $\begin{array}{l}25.85 \\
\pm 0.88\end{array}$ & $\begin{array}{c}6.39 \pm \\
0.82\end{array}$ & $\begin{array}{c}4.46 \\
\pm 1.46\end{array}$ \\
\hline \multirow{3}{*}{$\begin{array}{l}\text { Compound chocolate containing dried Indian } \\
\text { cherry fruit pulp powder with the ratio }(\%) \text { of }\end{array}$} & 20 & $\begin{array}{l}26.78 \\
\pm 1.03\end{array}$ & $\begin{array}{c}6.96 \\
\pm 1.06\end{array}$ & $\begin{array}{l}4.37 \\
\pm 0.45\end{array}$ \\
\hline & 30 & $\begin{array}{l}24.32 \\
\pm 2.06\end{array}$ & $\begin{array}{c}6.12 \\
\pm 0.97\end{array}$ & $\begin{array}{c}4.60 \\
\pm 0.63\end{array}$ \\
\hline & 40 & $\begin{array}{l}23.62 \\
\pm 1.54\end{array}$ & $\begin{array}{c}5.50 \\
\pm 0.69\end{array}$ & $\begin{array}{c}4.94 \\
\pm 1.37\end{array}$ \\
\hline \multicolumn{2}{|c|}{$\begin{array}{l}\text { Whole pieces of dried Indian cherry fruits pulp coated } \\
\text { with compound chocolate }\end{array}$} & $\begin{array}{l}26.47 \\
\pm 1.72\end{array}$ & $\begin{array}{c}6.49 \\
\pm 1.56\end{array}$ & $\begin{array}{c}4.51 \\
\pm 1.08\end{array}$ \\
\hline
\end{tabular}

Fat content, particle size distribution, moisture content, emulsifiers, conching time, and temperature affect rheological properties of chocolate product (Gonçalves and Lannes, 2010). Ashkezary et al. (2018) investigated the possibility of producing reduced fat dark compound chocolate and found that hardness of compound chocolate samples ranged from 32.09 to
53.25 N. As the Indian cherry fruit pulp increased in the studied chocolate samples, the chocolate components decreased particularly the fat component (because the Indian cherry fruits are poor in fats, Table 1) which mostly responsible for the softness of chocolate. This is may be led to the increase of firmness by increasing the fruit component (Table 3).

Table (3): Texture analysis of compound chocolate containing different levels of dried Indian cherry fruit pulp (whole pieces or grounded fruit)

\begin{tabular}{|c|c|c|c|}
\hline Sample & & $\begin{array}{l}\text { Firmness } \\
\text { (N) }\end{array}$ & $\begin{array}{l}\text { Work of shear } \\
\text { g. sec }\end{array}$ \\
\hline \multirow[t]{2}{*}{ Compound chocolate (control) } & & 2.46 & 598.63 \\
\hline & 20 & 7.88 & 3695.44 \\
\hline \multirow[t]{2}{*}{$\begin{array}{l}\text { Compound chocolate containing dried Indian cherry } \\
\text { fruit pulp powder with the ratio }(\%) \text { of }\end{array}$} & 30 & 15.99 & 5457.84 \\
\hline & 40 & 55.18 & 20781.88 \\
\hline \multicolumn{2}{|c|}{$\begin{array}{l}\text { Whole pieces of dried Indian cherry fruits pulp coated with } \\
\text { compound chocolate }\end{array}$} & 63.47 & 18261.53 \\
\hline
\end{tabular}

\section{Sensory properties:}

Sensory evaluation is a powerful scientific tool that can be used to identify variations in sensory properties and measure product's acceptability (SinghAckbarali and Maharaj, 2014). Sensory properties of compound chocolate containing different levels of dried Indian cherry fruit pulp (whole pieces or fruits powder) are presented in Table (4). The panelists recognized a new and clean taste for compound chocolate containing Indian cherry fruit pulp. All tested chocolate samples were strongly accepted from all panelists. According to the data, there were no significant differences $(\mathrm{p}<0.05)$ for colour, odour, flavour, sweetness, texture, melting quality and global quality for all studied chocolate samples, only astringency had a significant differences $(p<0.05)$. It could be referred that the addition of Indian cherry dried fruit pulp to chocolate manufacturing gave a new flavoured chocolate with no negative effect on the sensory attributes. 

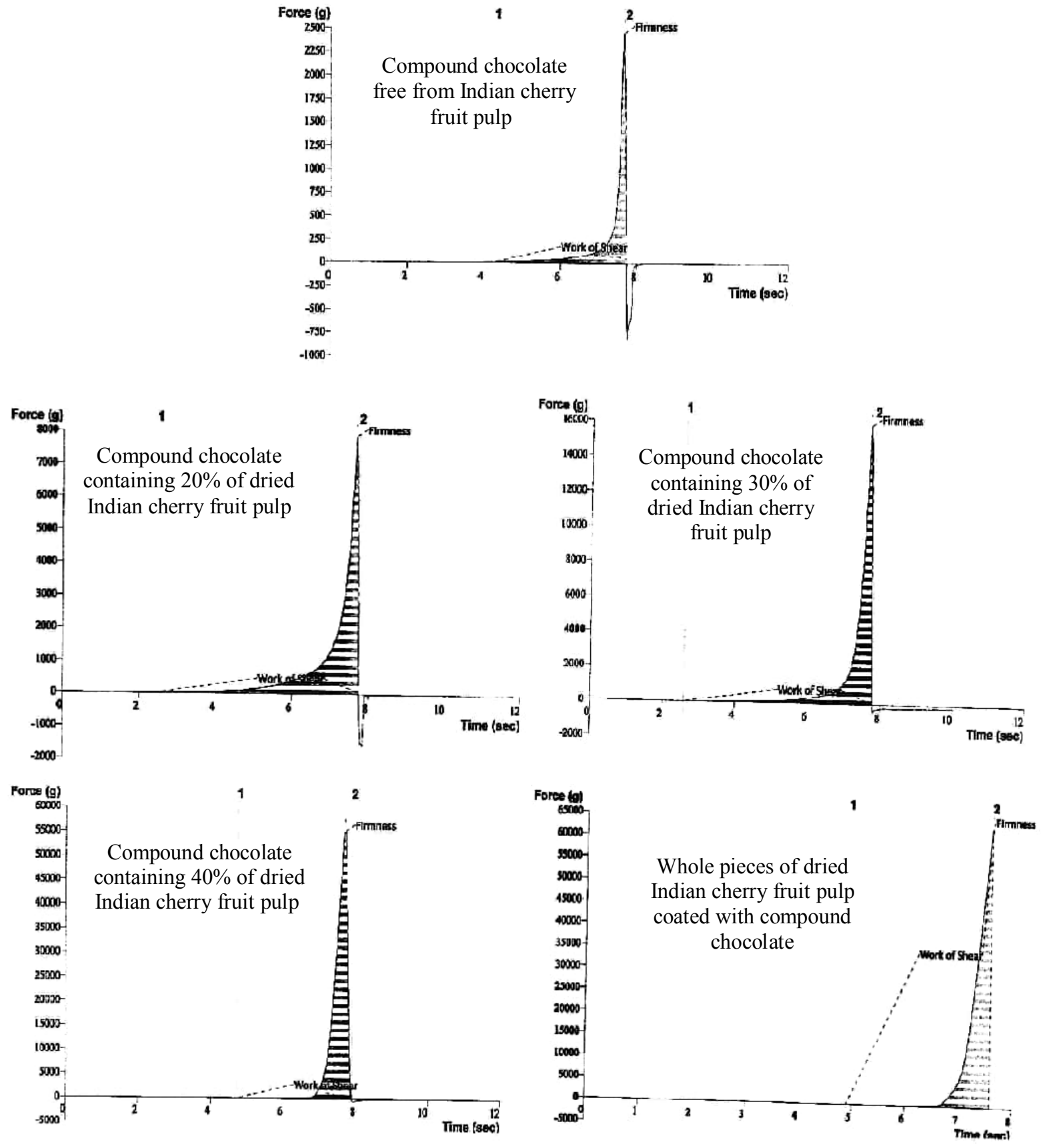

Figure (3): Texture analyzer TA.XT Plus curves of compound chocolate containing different levels of dried Indian cherry fruit pulp (whole pieces or grounded fruit). 
Table (4): Sensory properties (Mean \pm SD) of compound chocolate containing different levels of dried Indian cherry fruit pulp (whole pieces or grounded fruit)

\begin{tabular}{|c|c|c|c|c|c|c|c|c|}
\hline \multirow[b]{2}{*}{ Sample } & \multicolumn{8}{|c|}{ Sensory properties } \\
\hline & Colour & Odour & Flavour & Sweetness & Texture & $\begin{array}{l}\text { Melting } \\
\text { quality }\end{array}$ & Astringency & $\begin{array}{l}\text { Global } \\
\text { quality }\end{array}$ \\
\hline $\begin{array}{l}\text { Compound chocolate } \\
\text { (control) }\end{array}$ & $\begin{array}{c}8.34 \\
\pm 0.67\end{array}$ & $\begin{array}{l}8.05 \\
\pm 1.01\end{array}$ & $\begin{array}{l}7.27 \\
\pm 1.01\end{array}$ & $\begin{array}{c}8.34 \\
\pm 1.01\end{array}$ & $\begin{array}{c}6.82 \\
\pm 1.17\end{array}$ & $\begin{array}{l}7.82 \\
\pm 0.75\end{array}$ & $\begin{array}{l}8.18^{\mathrm{a}} \\
\pm 0.75\end{array}$ & $\begin{array}{c}8.07 \\
\pm 0.48\end{array}$ \\
\hline \multirow{3}{*}{$\begin{array}{l}\text { Compound chocolate } \\
\text { containing dried } \\
\text { Indian cherry fruit } \\
\text { pulp powder with the } \\
\text { ratio }(\%) \text { of }\end{array}$} & $\begin{array}{c}8.05 \\
\pm 1.06\end{array}$ & $\begin{array}{c}8.09 \\
\pm 0.86\end{array}$ & $\begin{array}{c}7.32 \\
\pm 1.10\end{array}$ & $\begin{array}{c}8.45 \\
\pm 0.82\end{array}$ & $\begin{array}{c}7.36 \\
\pm 0.50\end{array}$ & $\begin{array}{l}7.36 \\
\pm 0.92\end{array}$ & $\begin{array}{l}7.55^{\mathrm{ab}} \\
\pm 0.82\end{array}$ & $\begin{array}{l}7.91 \\
\pm 0.54\end{array}$ \\
\hline & $\begin{array}{c}8.27 \\
\pm 0.52\end{array}$ & $\begin{array}{c}8.02 \\
\pm 1.05\end{array}$ & $\begin{array}{l}7.59 \\
\pm 0.92\end{array}$ & $\begin{array}{c}8.55 \\
\pm 0.52\end{array}$ & $\begin{array}{c}7.45 \\
\pm 0.93\end{array}$ & $\begin{array}{c}7.36 \\
\pm 1.12\end{array}$ & $\begin{array}{l}7.55^{\mathrm{ab}} \\
\pm 1.13\end{array}$ & $\begin{array}{c}8.27 \\
\pm 0.90\end{array}$ \\
\hline & $\begin{array}{c}8.18 \\
\pm 0.90\end{array}$ & $\begin{array}{c}8.14 \\
\pm 1.05\end{array}$ & $\begin{array}{c}7.68 \\
\pm 0.98\end{array}$ & $\begin{array}{c}8.64 \\
\pm 0.67\end{array}$ & $\begin{array}{c}7.55 \\
\pm 1.13\end{array}$ & $\begin{array}{c}7.52 \\
\pm 1.10\end{array}$ & $\begin{array}{l}7.18^{\mathrm{b}} \\
\pm 0.60\end{array}$ & $\begin{array}{c}8.45 \\
\pm 0.69\end{array}$ \\
\hline $\begin{array}{l}\text { Dried Indian cherry fruit } \\
\text { pulp coated with compound } \\
\text { chocolate }\end{array}$ & $\begin{array}{c}8.05 \\
\pm 0.85\end{array}$ & $\begin{array}{c}8.09 \\
\pm 0.94\end{array}$ & $\begin{array}{l}7.95 \\
\pm 0.75\end{array}$ & $\begin{array}{c}8.64 \\
\pm 0.92\end{array}$ & $\begin{array}{c}7.55 \\
\pm 0.52\end{array}$ & $\begin{array}{c}7.05 \\
\pm 1.15\end{array}$ & $\begin{array}{l}7.45^{\mathrm{ab}} \\
\pm 0.69 \\
\end{array}$ & $\begin{array}{c}8.36 \\
\pm 0.67\end{array}$ \\
\hline F-test & N. S. & N. S. & N. S. & N. S. & N. S. & N. S. & $*$ & N. S. \\
\hline L. S. D. & - & - & - & - & - & - & 0.70 & - \\
\hline
\end{tabular}

\section{CONCLUSION}

It could be concluded that the enrichment of compound chocolate with dried Indian cherry fruit pulp produced a new flavoured compound chocolate product with good colour, hardness and sensory properties.

\section{REFERENCES}

Al-Hamdani and Hamdia M. S. (2017). A comparative study between the use of fruit Alpamber (Cordia myxa) and the industrial stabilizer in the ice cream industry. Int. J. Adv. Biol. Res., 7 (3): 564-567.

Andrae-Nightingale, L. M., S. Lee and N. J. Engeseth (2009). Textural changes in chocolate characterized by instrumental and sensory techniques. J. Texture Studies, 40: 427-444.

Anonymous (1986). MSTATC. Microcomputer Statistical Programme. Michigan State University, Michigan, Lansing, USA.

Ashkezary, M. R., S. Yeganehzad, H. Vatankhah, A. Todaro and Y. Maghsoudlou (2018). Effects of different emulsifiers and refining time on rheological and textural characteristics of compound chocolate. Ital. J. Food Sci., 30: 26-36.

El-kalyoubi M., M.F. Khallaf, A. Abdelrashid and Eman M. Mostafa (2011). Quality characteristics of chocolate - Containing some fat replacer. Annals Agric. Sci., 56(2): 89-96.
El-Newary, Samah A., A. M. Sulieman, S. R. El-Attar and M. Z. Sitohy (2016). Hypolipidemic and antioxidant activity of the aqueous extract from the uneaten pulp of the fruit from Cordia dichotoma in healthy and hyperlipidemic Wistar albino rats. J. Nat. Med., 70: 539-553.

Gonçalves, Estela V. and Suzana C. S. Lannes (2010). Chocolate rheology. Ciênc. Tecnol. Aliment., Campinas, 30(4): 845-851.

Hussain, N., B. Aya P. Agus, S. Nur F. Abdul Rahim and H. S. Abdul Halim (2018). Comparison of quality characteristics between compound and pure milk chocolate. MOJ Food Proc. Technol., 6 (3):292-296.

Jamkhande, G., R. Sonal, S. Barde, P. S. and Patwekar (2013). Plant profile, phytochemistry and pharmacology of Cordia dichotoma (Indian cherry): a review. Asian Pac. J. Trop. Biomed., 3 (12) 1009-1012.

Leite, P. B., E. D. S. Bispo and L. R. R. Santana (2013). Sensory profiles of chocolates produced from cocoa cultivars resistant to Moniliophthora Perniciosa. Rev. Bras. Frutic., Jaboticabal - SP, 35 (2): 594-602.

Macht, M. and D. Dettmer (2006). Everyday mood and emotions after eating a chocolate bar or an apple. Appetite, 46: 332-336.

Novaković, S. and I. Tomašević (2017). A comparison between Warner-Bratzler shear force measurement and texture profile analysis of meat and meat products: a review. $59^{\text {th }}$ 
International Meat Industry Conference, IOP Conf. Series: Earth and Environmental Science 85: 012063, IOP Publishing, doi: $10.1088 / 1755-1315 / 85 / 1 / 012063$.

Patil, D.N., A.R. Kulkarni, A.A. Shahpurkar and B.S. Patil (2010). Release of drug neomycin from Cordia dichotoma transdermal film. Inter. J. Pharma Bio. Sci., 1(2): 597-600.

Pawar, H. A., A. J. Gavasane and P. D. Choudhary (2018). Extraction of polysaccharide from fruits of Cordia dichotoma G. Forst using acid precipitation method and its physicochemical characterization. Inter. J. Biol. Macromol., 115: 871-875.

Pawar, H. and A., P. Jadhav (2015). Isolation, characterization and investigation of Cordia dichotoma fruit polysaccharide as herbal excipient. Inter. J. Biol. Macromol., 72: $1228-1236$.

Popov-Raljic, J. V. and J. G. Lalicic-Petronijevic (2009). Sensory properties and color measurements of dietary chocolates with different compositions during storage for up to 360 days. Sensors, 9: 1996-2016.

Rajashekar, K., M. K. Thupurani, S. Marupati, T. S. Prasad and K. Reddy (2014). Cordia dichotoma crude extracts: potent source of natural antibacterial and antioxidant agents. Inter. J. Adv. Res., 2 (2): 65-73

Ranganna, S. (2003). Hand book for analysis and quality control for fruit and vegetables products, 2nd ed. Tata McGraw Hill Pub. Co. Ltd. New Delhi.

Rosales, C. K., U. Klinkesorn and S. Suwonsichon (2017). Effect of crystal promoters on viscosity and melting characteristics of compound chocolate. Inter. J. Food Proper. 20 (1): 119-132.
Serafini, M., R. Bugianesi, G. Maiani, S. Valtuena, S. De-Santis and Crozier A. (2003). Plasma oxidants from chocolate. Nature, 424: 10131018.

Singh-Ackbarali, D. and R. Maharaj (2014). Sensory evaluation as a tool in determining acceptability of innovative products developed by undergraduate students in Food Science and Technology at The University of Trinidad and Tobago. J. Curriculum Teaching, 3(1): 10-27.

Steel, R.G.D., J.H. Torrie and D.A. Dicky (1997). Principles and procedures of statistics, a biological approach. $3^{\text {rd }}$ ed. MacGraw Hill Book Co., New York, USA.

Talbot, G. (2009). Introduction in science and technology of enrobed and filled chocolate, confectionery and bakery products. Woodhead Publishing Limited: Cambridge, United Kingdom, p.1-10.

Toliba, A. O. (2012). Physico-chemical properties and sensory attributes of drinks produced from pomegranate and Indian cherry blends. Zagazig J. Agric. Res., 39 (6): 1175-1183.

Toliba, A. O. (2018). Impact of drying pretreatments on the quality characteristics of Indian cherry fruit pulp. J. Food and Dairy Sci., Mansoura Univ., 9 (10): 347 - 351.

Valvi, S. R. and V.S Rathod (2011). Mineral composition of some wild edible fruits from Kolhapur district. Inter. J. Applied Biol. and Pharmac. Technol., 2(1): 392-296.

Vidyasagar, G., A. G. Jadhav, S. P. Narkhede and S. B. Narkhede (2010). Isolation and comparative evaluation of Cordia dichotoma Forst. mucilage as a binding agent with standard binder. J. Chem. Pharm. Res., 2(4):887-891.

\footnotetext{
خصائص الجودة للشيكولاتة المركبة المدعمة بلب ثمار الكريز الهندي المجفف قسم علوم الأغذية _ كلية الزراعة عمر طليبة جامعة الزقازيق - مصر

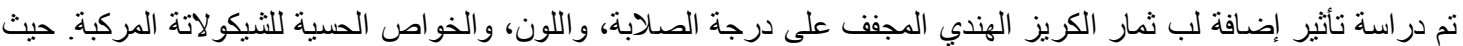

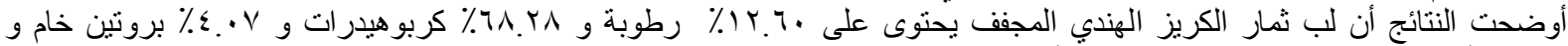

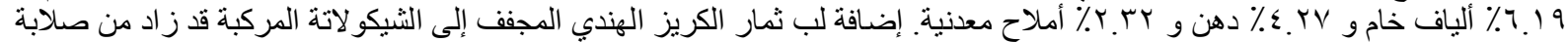

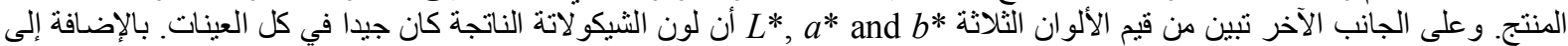

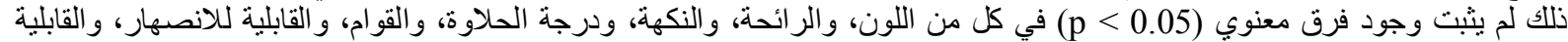

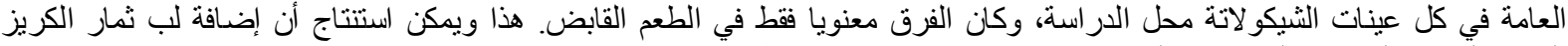
الهندي المجف لصناعة الثيكو لاتة المركبة نتج عنه منتج شيكو لاتة ذو طعم وخو اصل في الطعية جيدة.
} 